\title{
Indicative value of non-pollen palynomorphs (NPPs) and palynofacies for palaeoreconstructions: Holocene Peat, Brazil
}

\author{
Svetlana Medeanic*, Maristela Bagatin Silva \\ LOG, IO, FURG, Av. Itália km 08, Rio Grande, CEP 96.201-900, RS, Brazil
}

\section{A R T I C L E I N F O}

\section{Article history:}

Received 23 February 2010

Received in revised form 26 August 2010

Accepted 26 August 2010

Available online 17 September 2010

\section{Keywords:}

Palynomorphs

Algae

Fungi

Organic matter

Southern Brazil

\begin{abstract}
A B S T R A C T
The results of the palynological study of the samples from the core, performed in the Aguas Claras peatland, RS, Brazil $\left(50^{\circ} 45^{\prime} 00^{\prime \prime} \mathrm{W}, 30^{\circ} 00^{\prime} 15^{\prime \prime} \mathrm{S}\right)$, focus on detailed taxonomic analysis of non-pollen palynomorphs (NPPs) and palynofacies from the Holocene peat and underline the Late Pleistocene mud and sandy mud that were represented. NPPs from the samples revealed taxonomic variety of fungal palynomorphs, presented by Brachysporium, Clastesporium, Dicellaesporites, Dicellaeporisporites, Gelasinospora, Glomus, Sordaria, Helicoon, and others. The habitats of above mentioned taxa are varied: aquatic, mycorrhizal, parasitic, organic matter decaying, and dung-coprophilous. Freshwater algal palynomorphs were composed of Botryococcus, Closterium, Debarya, Mougeotia, Pseudoschizaea, Spirogyra, and Zygnema. The percentage ratio between algal and fungal palynomorphs was changed from the different samples of the core, reflecting climatic oscillations (more humid-dryer). Prevalence of fungal palynomorphs was connected with dryer climate, and on the contrary, freshwater algal palynomorph predominance was related with increasing humidity. The six palynomorph zones that corresponded to the six principal phases of environmental and climatic changes were determined. The zone from the uppermost part of peat was characterized by relatively frequent dungcoprophilous and parasitic fungi, as a result of agricultural and domestic activities. Palynofacies analysis combined to NPPs was used for palaeoenvironmental and paleoclimatic reconstructions. Palynofacies from the samples were characterized by evident changes in relationship (\%) between the different types of organic matter, their quality, and quantity and fluorescence index. The obtained data contribute to the understanding of the peat deposition. The combined use of NPPs and palynofacies analyses provided a valuable approach for the paleoenvironmental and paleoclimatic reconstructions.
\end{abstract}

(c) 2010 Elsevier B.V. All rights reserved.

\section{Introduction}

The implications of non-pollen palynomorphs (NPPs) for paleoreconstruction of the Quaternary sediments are elaborated by many palynologists of the world. The principal and the most frequent from the sample NPPs are algal and fungal palynomorphs. The use of NPPs, composed of resistant sporopollenin-like polymer or chitin, frequently may be more informative for palaeoreconstructions than more delicate sporopollenin composed pollen and spores of vascular plants (van Geel, 2006).

Several publications have shown the importance of freshwater algal palynomorphs for palaeoecological interpretations as indicative for the depth, salinity, temperature, $\mathrm{pH}$, and nutrient status parameters of aquatic palaeoenvironments (Hoshaw and McCourt, 1988; Komárek and Jankovská, 2001; Rull et al., 2008; van Dam et al., 1988; van Geel, 1976; van Geel and van der Hammen, 1978; van Geel et al., 1980, 1986). Fungal palynomorphs are usually represented by

\footnotetext{
* Corresponding author. Tel.: + 5553 32336794; fax: + 555332336605 . E-mail address: svetlanamedeanic@furg.br (S. Medeanic).
}

ascomycete remains, ascospores, and hyphoidia (Traverse, 1988). The use of fungal palynomorphs for palaeoreconstruction is very important, especially when other palynomorphs were absent in palynological slides. According to van Geel and Aptroot (2006), the recorded fungal palynomorphs are of strictly local occurrence. Their fossilization occurred near the place where they had been produced or were deposited at a short distance from the place where sporulation took place. Fungal palynomorphs are diverse by their ecology and habitat - parasitic, symbiotic, mycorrhizal, coprophilous, and cellulose decomposing, and fungi occurred on burnt remains.

Reports on biological affinities of fungal palynomorphs and their ecology are relatively scarce in literature (Pals et al., 1980; van Geel and Andersen, 1988; van Geel and Aptroot, 2006; van Geel et al., 2003). By this reason, many palynologists use informal classification for fungal palynomorphs based on their morphology (Elsik, 1983; Jansonius and Kalgutkar, 2000; Jarzen and Elsik, 1986). There are many ambiguities with fungal palynomorph identifications and consequently knowledge of their ecology makes palynological interpretations difficult.

Palynofacies analysis is the study of particulate organic matter assemblages (sensu Boulter and Riddick, 1986), concerned with 


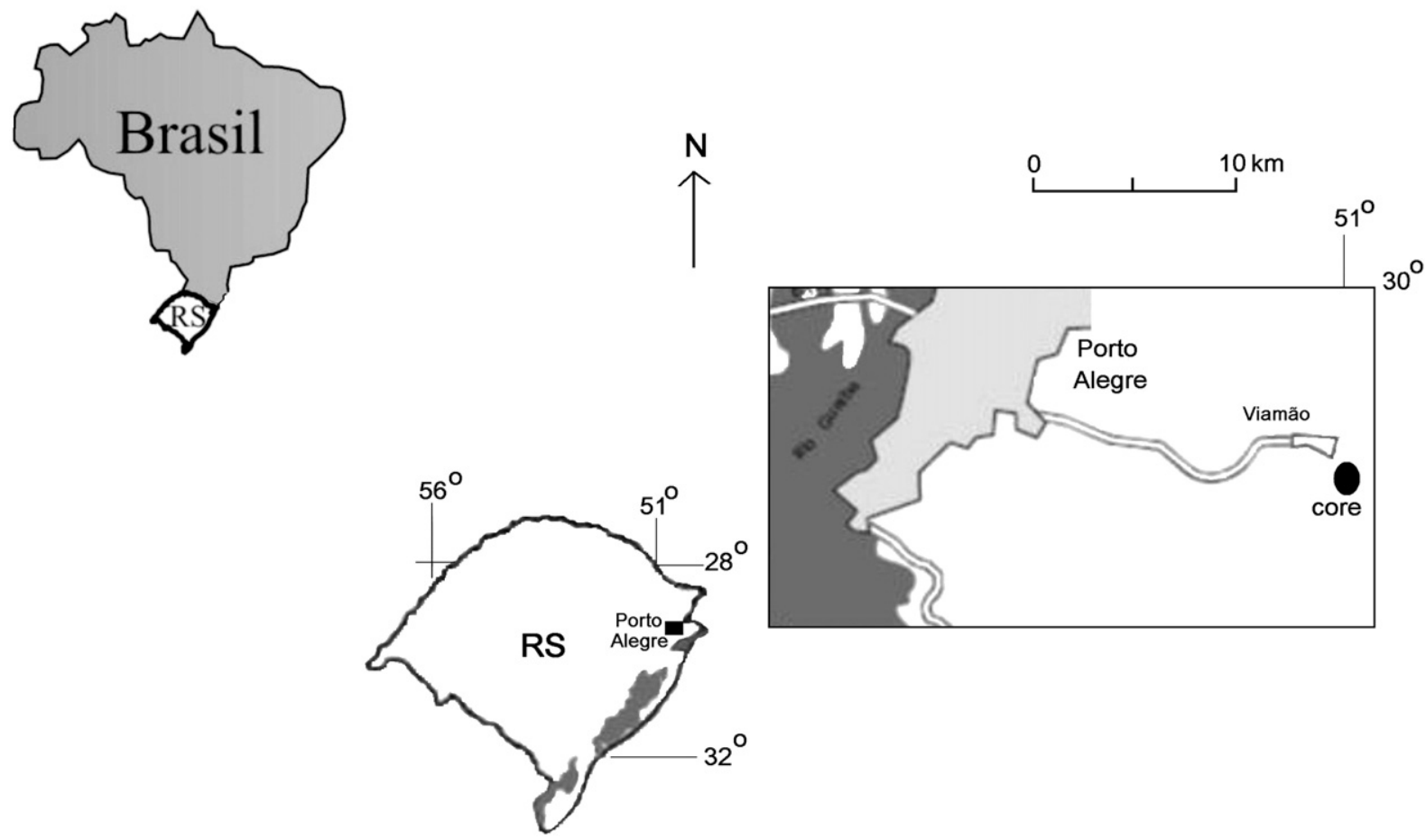

Fig. 1. The map showing locality of the core in Aguas Claras peat land.

changes in the relative abundance of various types of organic debris. According to Batten (1987), an understanding of the sedimentary context of a particular palynofacies is essential if an environmental interpretation is to be more than broadly based. Changes in paleonvironmental and paleoclimatic conditions may be inferred from differences in the composition of total organic matter.
Peat, composed predominantly of organic matter remains, is favorable material for the palynological study of NPPs and palynofacies. Palynological study of the Quaternary peat in Brazil showed a great variety of NPPs, especially fungal palynomorphs and freshwater algal palynomorphs of Chlorophyta (Garcia, 1997; Medeanic, 2006; Medeanic et al., 2008).

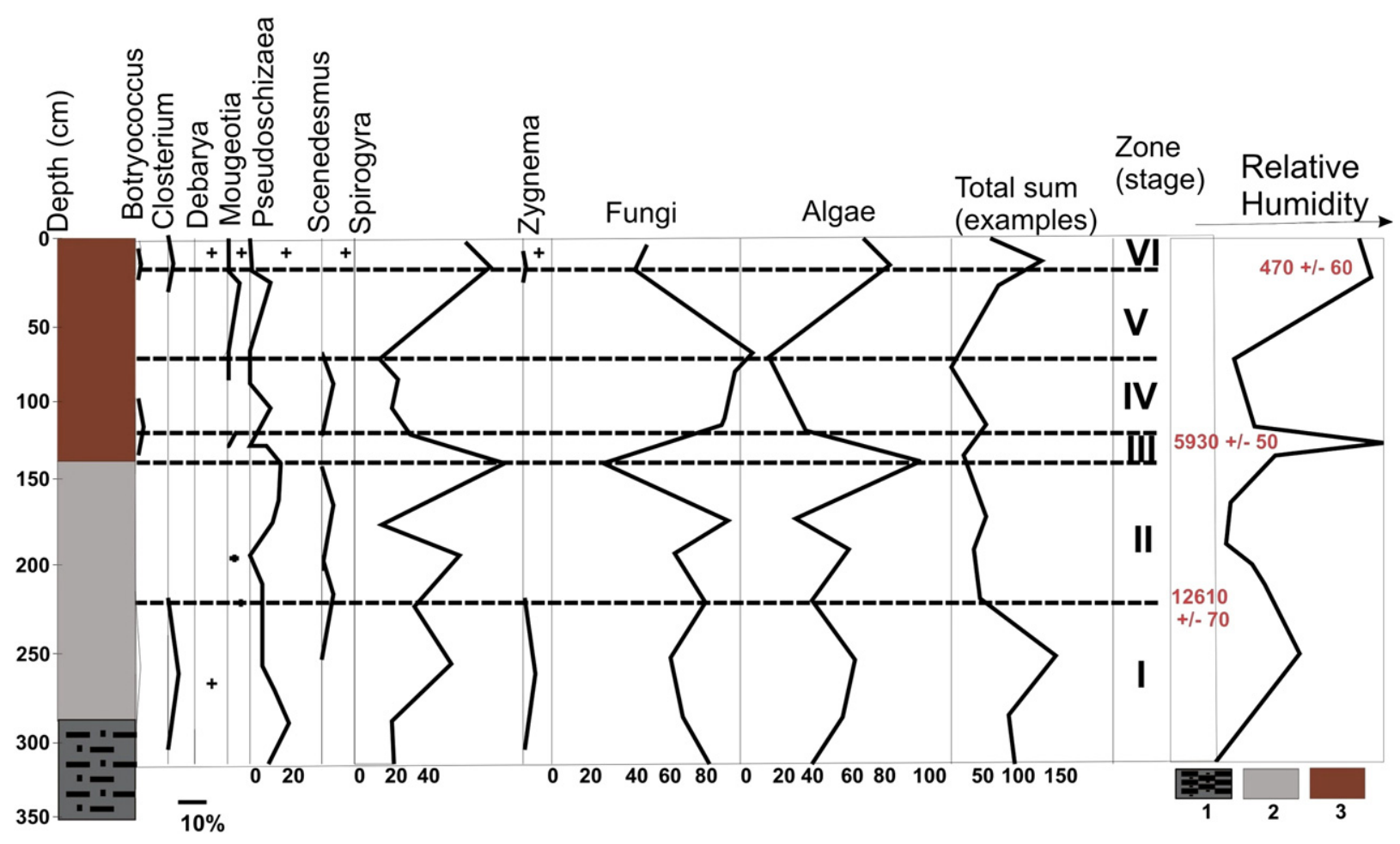

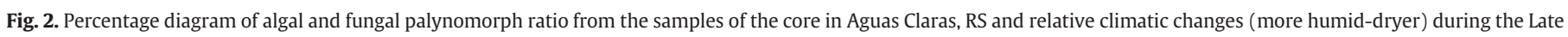
Pleistocene and Holocene: 1 - sandy mud, 2 - mud, and 3 - peat (modified from Barbosa et al., 2003). 
Aguas Claras region is situated in the Rio Grande do Sul State (RS), $35 \mathrm{~km}$ east far from Porto Alegre, near Viamão township, in the southern border of the Gravataí River Basin (Fig. 1). This peatland represents a small valley and belongs to the Lagoon/Barrier IV system having elongate outline. The dimension of peatland is $3 \times 5 \mathrm{~km}^{2}$ (Villwock et al., 1980). Peatland was deposited similarly to the mire which has been found at the backshore and interdune area next to coastal plains in RS. The peat was deposited above intercalated sediments of sand, silt and mud varying in lithology and thickness of vertical and horizontal profiles. The thickness of peat in the different points of this peatland is varying (1.6-4.8 m). It is one of the most important the Holocene peat deposits in Brazil occupied area of 3125.1 ha where peat in situ resources reach 61,766 tons. There is no overburden. The most valuable portion of fibrous peat with low ash content is situated closely to the surface and may be easily used for agriculture. Analytical results indicate ash content by $25 \%$ and calorific value on dry basis over $4200 \mathrm{kcal} / \mathrm{kg}$, mainly in the upper stratum (Süffert, 1998). At present, this region is widely occupied by agricultures that use peat as suitable substances for vegetable planting (Süffert, 1998).

In this paper, we discuss our previous palynological data from the samples of one core, drilled in the Aguas Claras peatland, RS, Brazil and present our revised results, based on NPPs and palynofacies analyses in order to reevaluate environmental and climatic interpretations and to show the importance of these analyses applied together.

The first palynological study of this peat revealed in preliminary results (Burjack and Marques-Toigo, 1980) that many palynomorphs were illustrated but not identified, and some algal palynomorphs were confused with pollen of angiosperms and spores of ferns. More than twenty years later, pollen and spores of terrestrial and aquatic plants and algal and fungal palynomorphs (in sensu lato) from the samples of the core performed in that peatland and dated by ${ }^{14} \mathrm{C}$ were published by Barbosa et al. (2003). The three palynomorph zones and the three palynomorph subzones, corresponding to climatic changes that occurred during the Late Pleistocene and the Holocene were described.

\section{Material and methods}

\subsection{Sampling}

In the studied core $\left(50^{\circ} 45^{\prime} 00^{\prime \prime} \mathrm{W}, 30^{\circ} 00^{\prime} 15^{\prime \prime} \mathrm{S}\right)$, the peat is underlain by mud. The thickness of studied sequence was about $320 \mathrm{~cm}$ (Fig. 2). The three data were obtained in Beta Analytic Lab. $-12610+/-70$ yrs BP (lab. 166442 Beta Analytic), 5930 +/-50 AP (lab.1664443 beta Analytic) yrs BP, and $470+/-60$ yrs BP (lab. 166444 Beta Analytic) (Barbosa et al., 2003).

\subsection{Chemical treatment}

The 14 samples were first desiccated in a furnace under a temperature of $60{ }^{\circ} \mathrm{C}$, then $50 \mathrm{~g}$ was treated with $\mathrm{HCl}(10 \%)$ and $\mathrm{KOH}$ (5\%), and boiled for $10 \mathrm{~min}$ (Faegri and Iversen, 1975). The chemical treatment of the HF was avoided. We did not use centrifuge in order to preserve the organic particle's original size. Inorganic substances were separated from the organic matter by "dense liquid" - aquatic solution of $\mathrm{ZnCl}_{2}$ at $2.2 \mathrm{~g} / \mathrm{cm}^{3}$ density. The residual materials were mounted on glycerol-jelly for the permanent slide preparing. All slides under numbers 132P-145P are preserved in the Laboratory of Oceanographic Geology of the Institute of Oceanography, FURG.

\section{Table 1}

Taxonomic variety of fungal palynomorphs from the Late Pleistocene (palynomorph zones I and II) and Holocene (palynomorph zones III-VI) samples of core in Aguas Claras peat land: + (present), - (absent).

\begin{tabular}{|c|c|c|c|c|c|c|}
\hline \multirow{4}{*}{$\begin{array}{l}\text { Fungal } \\
\text { palynomorphs }\end{array}$} & \multicolumn{6}{|c|}{ Palynomorph zone } \\
\hline & I & II & III & IV & V & VI \\
\hline & \multicolumn{6}{|c|}{ Depth (cm) } \\
\hline & $220-320$ & $135-220$ & $115-135$ & $70-115$ & $30-70$ & $0-30$ \\
\hline Brachysporium & + & & - & - & + & + \\
\hline $\begin{array}{l}\text { Byssothecium } \\
\text { cf. circinans }\end{array}$ & - & - & - & - & - & + \\
\hline Chaetomium & - & + & - & - & - & + \\
\hline Clastesporium & & - & - & - & + & + \\
\hline Coniochaeta & - & - & - & - & - & + \\
\hline Dicellaesporites & + & + & + & + & + & + \\
\hline Dicellaporisporites & + & + & + & + & + & + \\
\hline Dydimoporisporonites & + & + & + & + & + & + \\
\hline Fusiformisporites & + & - & - & - & - & + \\
\hline Gelasinospora & & + & - & + & + & - \\
\hline Glomus & + & + & + & + & + & + \\
\hline Helicoon & - & - & - & - & - & + \\
\hline Type I01 & - & - & - & - & - & + \\
\hline Type IO2 & - & - & - & - & + & - \\
\hline Lacrimasporonites & - & + & - & + & - & + \\
\hline Mycoraceae? & - & + & - & - & - & + \\
\hline Neurospora & - & - & - & + & & - \\
\hline Podospora & - & - & - & - & - & - \\
\hline Sordaria & - & & - & - & - & + \\
\hline Sporormiella & - & - & - & - & - & + \\
\hline Tilletia & - & - & - & - & - & + \\
\hline Ustulina? & - & + & - & - & - & - \\
\hline Valsaria & - & - & - & - & - & + \\
\hline Total sum of taxa & 6 & 9 & 4 & 7 & 8 & 18 \\
\hline
\end{tabular}

\subsection{NPPs study}

For identification of fungal palynomorphs, we used available literature (Jansonius and Kalgutkar, 2000; Pals et al., 1980; Parsons and Norris, 1999; van Geel and Andersen, 1988; van Geel and Aptroot, 2006). Many palynomorphs were identified according to their biological affinity (Limaye et al., 2007; van Geel and Aptroot, 2006). Some fungal palynomorphs were identified according to informal classification, revised by Parsons and Norris (1999), and a few palynomorphs have not been identified yet and which were labeled as Type IO1 and Type IO2. All identified taxa of fungal palynomorphs were represented in Table 1.

Freshwater algal palynomorphs were identified using van Geel (1976), van Geel and van der Hammen (1978), and van Geel et al. (1980).

Relative frequencies of algal and fungal palynomorphs from the samples were shown in plotted diagram (Fig. 2), using the Tilia Software, designed by Grimm (1987). Photomicrographs of most encountered NPPs were made using Lobomed-400 microscope with 400 magnifications (Figs. 3 and 4).

\subsection{Palynofacies analyses}

The microscope examination of organic matter was carried out using a Leitz microscope which allows transmitted and reflected light observations using oil immersion objectives. Several classifications for dispersed organic matter were present (Batten, 1996; Boulter and Riddick, 1986; Tyson, 1995; van Bergen et al., 1990). In this study, we have used a simplified scheme adapted to Tyson's

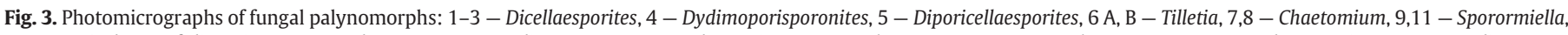

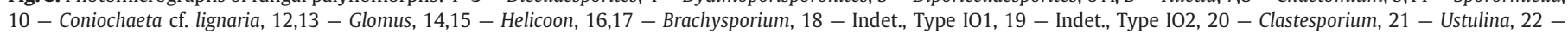
Podospora, 23 - Sordaria?, 24 - Byssothecium cf. circinans, 25 - Mycoraceae?, 26 - Neurospora, 27 - Valsaria, 28 - Gelasinospora, and 29 - Fusiformisporites. Scale - 30 um. 

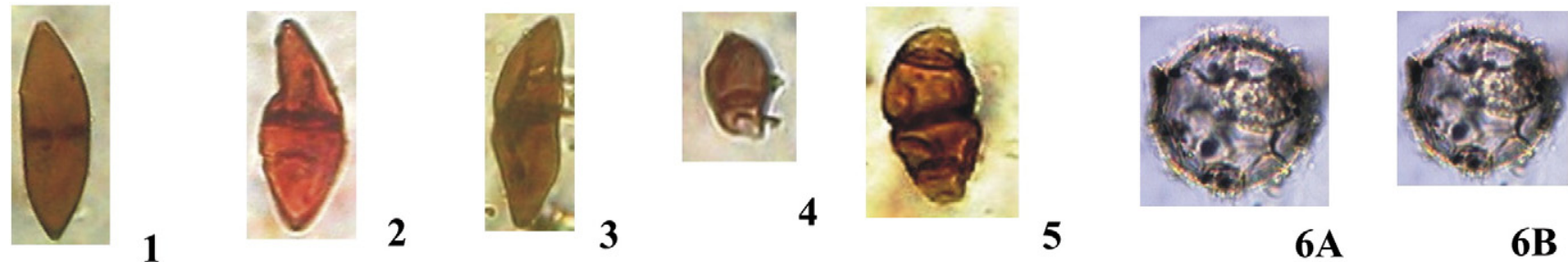

5

$6 A$

6B
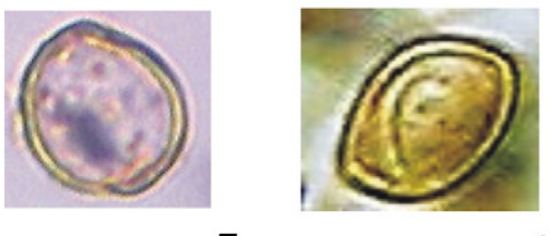

7

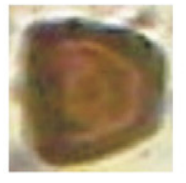

9

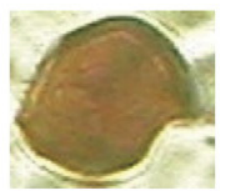

10

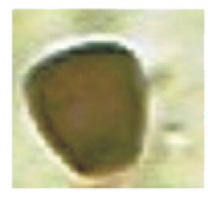

11

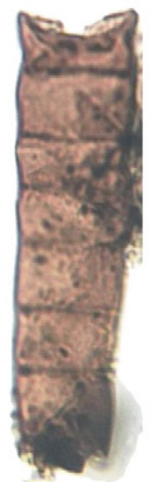

17

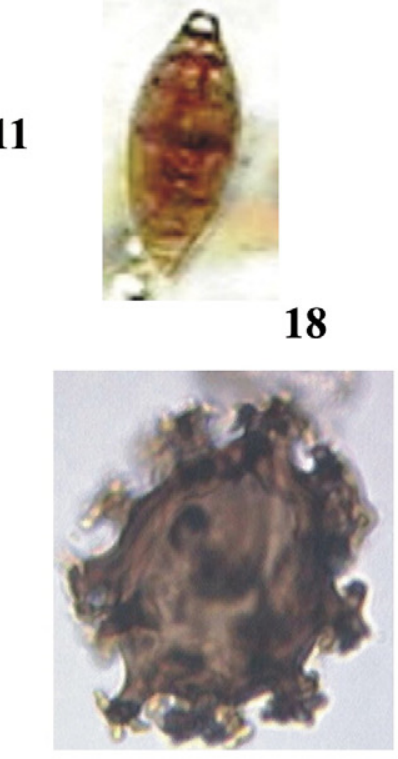

19

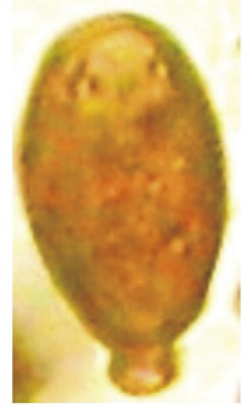

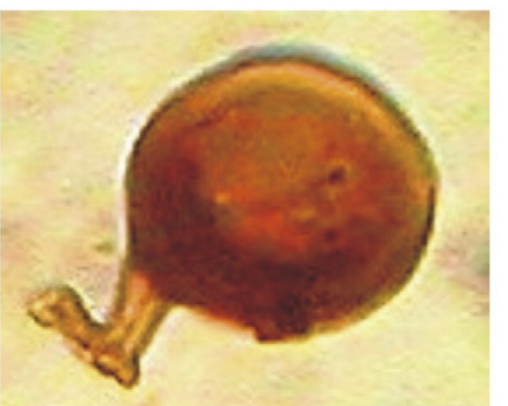

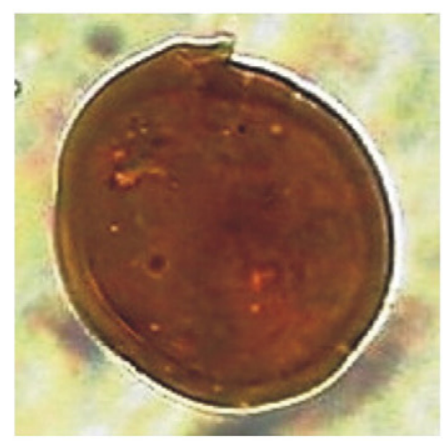

13
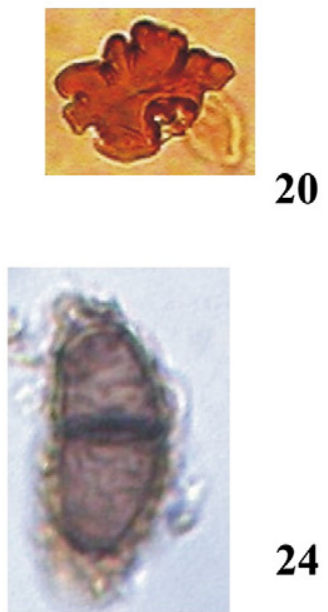

24

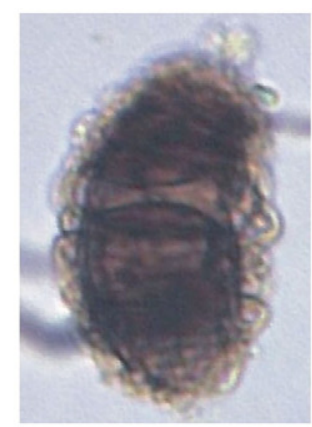

12
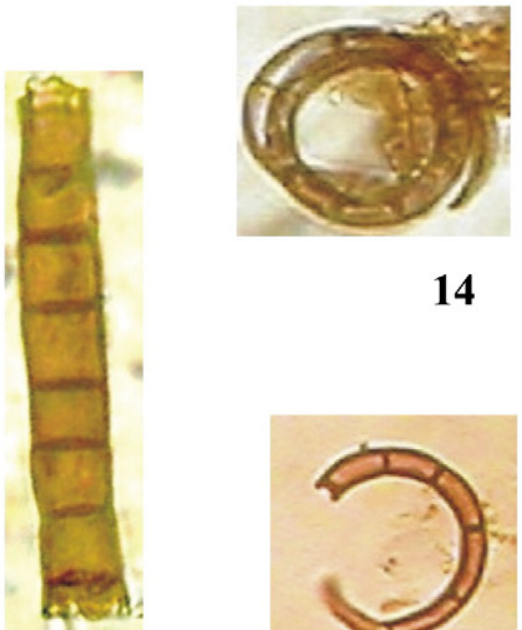

14

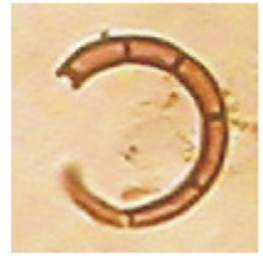

16

15
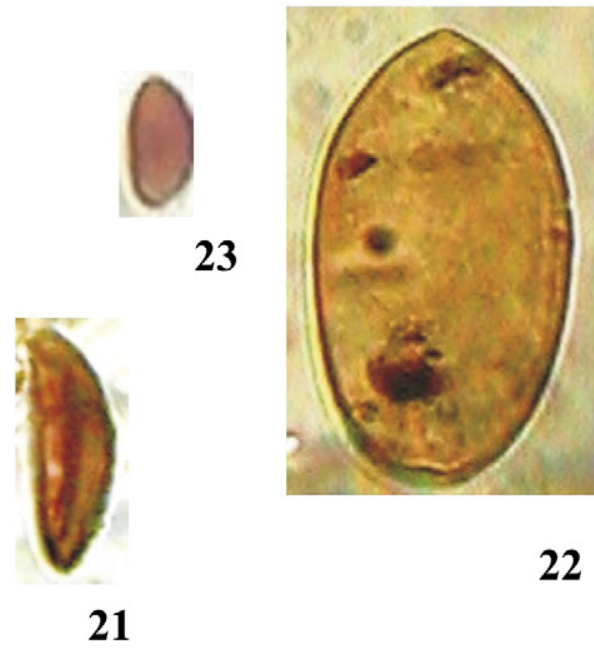

22

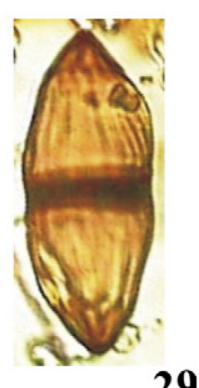



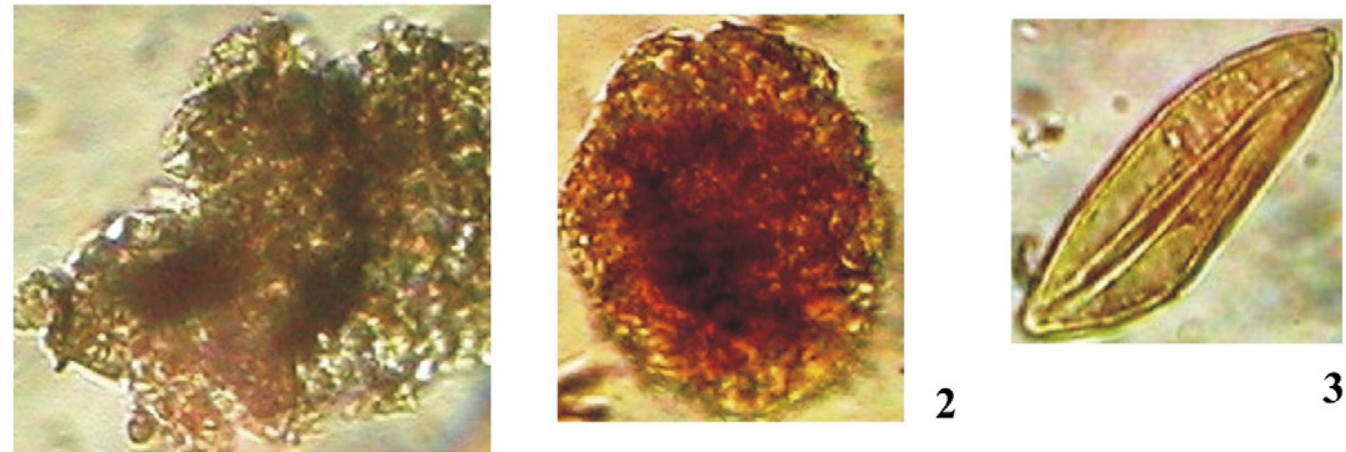

1
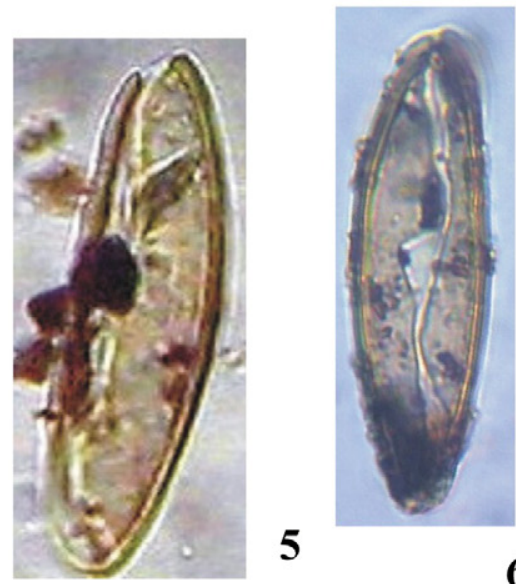

5
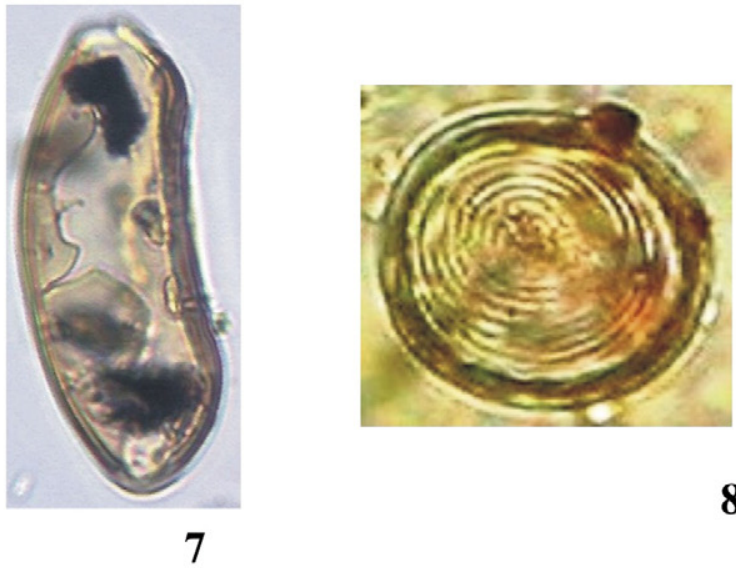

8

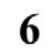

3

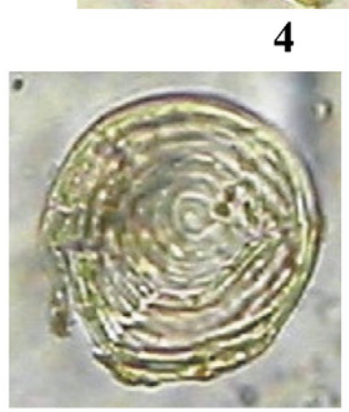

10

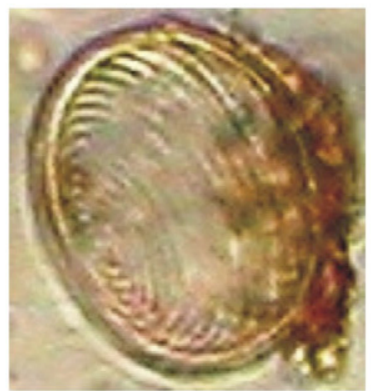

11

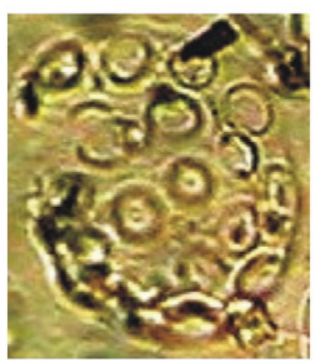

12
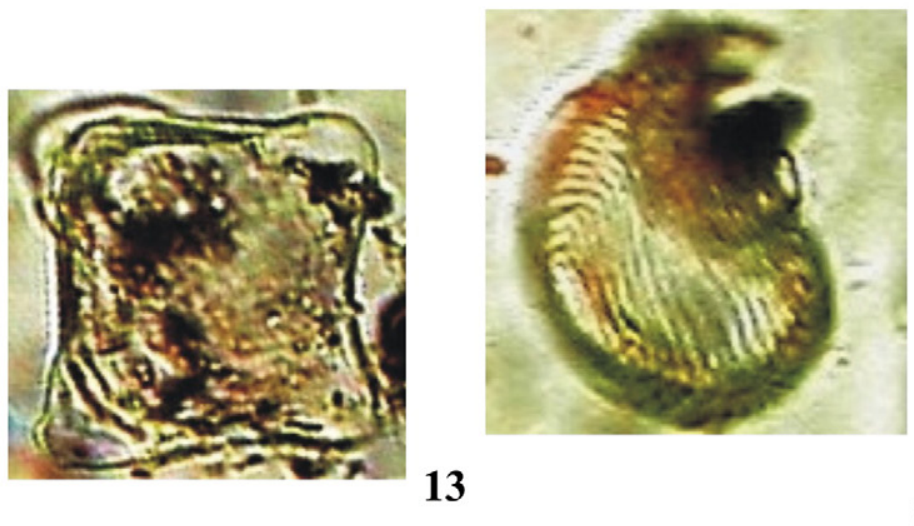

9

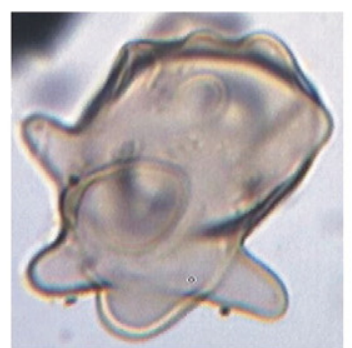

17A
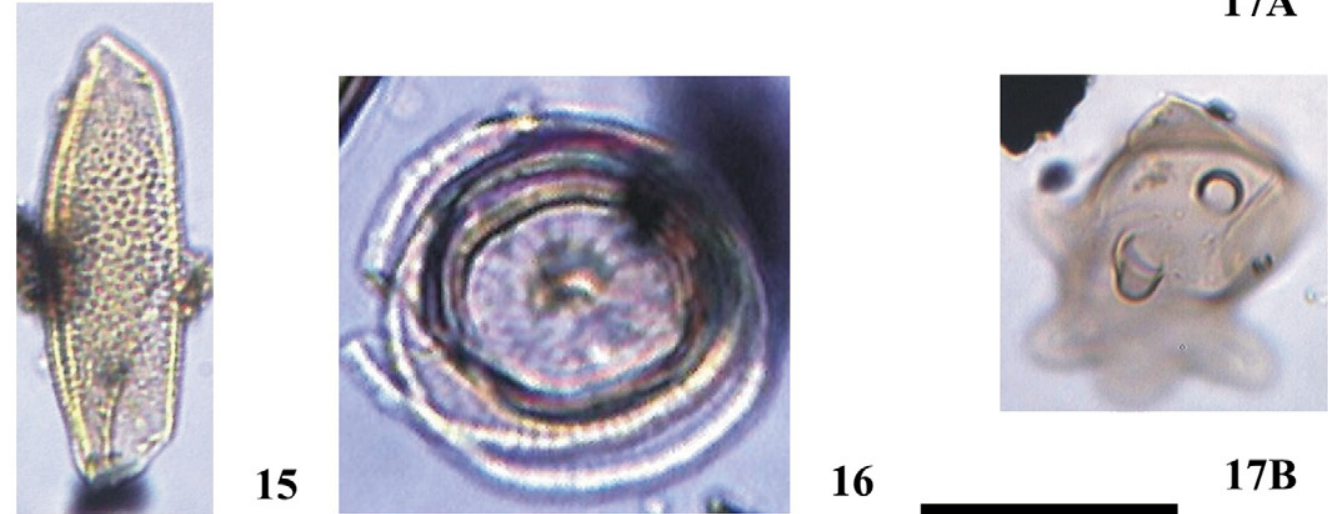

16

17B

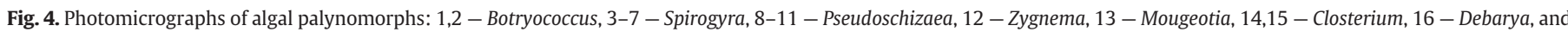
17 - indet. Type IO3. Scale $-30 \mu \mathrm{m}$. 
classification (1995), including phytoclast group, amorphous (AOM) and pseudoamorphous organic matter, and palynomorph group. Photomicrographs of the different types of organic particles were shown in Fig. 5. At least, 300 particles of organic matter per sample were counted and converted to percentages (Table 2 and Fig. 6).

\section{Results and discussion}

\subsection{NPPs characteristics}

A revision of NPPs from the samples revealed a taxonomic variety of fungal and algal palynomorphs. Fungal palynomorphs were represented by Brachysporium, Clastesporium, Coniochaeta, Dicellaesporites, Dicellaeporisporites, Gelasinospora, Glomus, Ustulina, Helicoon, and Podospora (Fig. 3, Table 1). Algal palynomorphs were relatively diverse, consisted mainly of freshwater microalgae of Botryococcus, Closterium, Debarya, Mougeotia, Pseudoschizaea, Spirogyra, and Zygnema (Fig. 3).

\subsection{Palynofacies variety}

The different identified palynofacies types were: amorphous (AOM), pseudoamorphous, solid, tabular and opaque, angular and fragmentary organic translucent and opaque particles, and charcoal (Fig. 5). Variation in the percentage of AOM, pseudoamorphous phytoclasts, and palynomorphs from the samples was shown in Fig. 6 and in Table 2.

\subsection{Palynomorph zones and palinofacies}

The remarkable variation in diversity of algal and fungal palynomorphs and their relationship may be used as important parameter for palaeoenvironmental and paleoclimatic changes in the past. Increase in portion of fungal palynomorphs from sediments was connected with dryer climate, and fewer frequencies of fungal palynomorphs might be the reason of more humid climate. An increase of algal palynomorph occurrences was related with pluviosity intensification that influenced the hydrodynamic conditions of sedimentation. The six palynomorph zones that correspond to six principal climatic changes were determined. According to ${ }^{14} \mathrm{C}$ dating, palynomorph zones I and II corresponded to the Late Pleistocene, and zones III-VI were formed during the Holocene (Fig. 2). Description of palynomorph zones by NPPs was accompanied by palynofacies characteristics. The Late Pleistocene lithofacies in the Aguas Claras peatland were dominantly beds of mud (zones I and II). Zone I was dominated by mud and sand, meanwhile zone II was represented predominantly by mud. The Holocene succession consisted of peat (zones III-VI). Palynofacies analysis was made for every palynomorph zone.

Below, the characteristic of palynomorph zones accompanied by palynofacies description was given. The approached palaeoenvironmental and palaeoclimatic reconstructions for every phase (time, corresponding to zone) was made.

I zone, depth $220-320 \mathrm{~cm}$, mud and sand in the lower part and recovering uppermost by mud. Algal and fungal palynomorphs were found in approximately equal proportion (Fig. 2). Fungal palynomorphs were represented by informal taxa of Brachysporium, Dicellaesporites, Dicellaeporisporites, Dydimoporisporonites, Fusiformisporites, and Glomus. Relatively frequent Glomus may be indicative for the erosion process increasing as a result of dryer and continental climate (Limaye et al., 2007). Freshwater algal palynomorphs were represented by Mougeotia, Zygnema, Spirogyra, Debarya, and Pseudoschizaea. The presence of Debarya was indicative for the lower than present temperature (van Geel and van der Hammen, 1978).
Palynofacies consist mostly of AOM (54-68\%), except at top, which was dominated by phytoclast group (50\%) (Table 2). AOM was not fluorescent, and probably its origin was from degraded matter from the land. Probably, abundant opaque phytoclasts at the top of zone were carbonized organic material. The major proportion of opaque phytoclasts (carbonized?) and lack of fluorescence of amorphous organic matter may indicate partial oxidation before or during sediment deposition (Tyson, 1995).

Climate was more humid than during the previous phase and dryer at the final phase and, probably, the temperature was lower than actual. It was confirmed by pollen records of Chenopodiaceae, Rubiaceae, Vernonia, and more scarce pollen of arboreal plants (Barbosa et al., 2003).

II zone, depth $135-220 \mathrm{~cm}$, mud. This zone was characterized by poor palynomorph diversity. Many of them had bed preservation. The fungal palynomorphs were predominant. The most common and frequent was Glomus. Other fungal palynomorphs were represented by rare Dicellaesporites, Dicellaeporisporites, Dydimoporisporonites, and Lacrimasporonites. Sporadic Gelasinospora and Chatomium were registered too. Besides Glomus, indicative for the active erosion processes, Gelasinospora records were interpreted as evidence for dry oligotrophic conditions (van Geel and Aptroot, 2006). Algal palynomorphs were extremely scarce (only Spirogyra and Pseudoschizaea records), indicating water table lowering as a result of decreasing pluviosity.

Palynofacies consisted mainly of amorphous organic matter (45$62 \%$ ), followed by pseudoamorphous phytoclast solid, tabular, and opaque phytoclasts, which suggested an oxidized/carbonized and allochtonous deposition (Table 2).

Climate was dry and more continental. A few palynomorph occurrences, very rare pollen and spores of vascular plants, predominance of indicative fungal palynomorphs, and charcoal particles indicated relatively dry and continental climate that corresponded to the final of the Late Pleistocene, more precisely - Last Glacial Period (Wisconsian).

III zone, depth $115-135 \mathrm{~cm}$, peat. Freshwater algal palynomorphs were more frequent than fungal palynomorphs. They were represented by Mougeotia (predominant), Spirogyra, and Pseudoschizaea. Fungal palynomorphs were sporadic, their taxonomic variety was restricted. Only informal genera of Dicellaeporisporites, Dicellaesporites, Dydimoporisporonites, and mycorrhizal Glomus were encountered.

Palynofacies consisted mainly of brown pseudoamorphous phytoclasts and opaque phytoclasts (Table 2). Climate was more humid and temperatures were higher than in previous phase.

IV zone, depth 70-115 cm, peat. Fungal palynomorphs were more frequent than algal palynomorphs, presented by Dicellaeporisporites, Dicellaesporites, Dydimoporisporonites, Gelasinospora, Glomus, and Lacrimasporonites. Besides, Neurospora, indicative for the fires was met. Algal palynomorphs were sporadic, some examples of Botryococcus and Spirogyra were found. Both Gelasinospora and Botryococcus were indicated on dryer climate and oligotrophic environmental conditions (Guy Ohlson, 1992; van Geel and Aptroot, 2006). Above mentioned NPPs were associated with scarce pollen and spores of vascular plants with predominance of pollen of Poaceae, Asteraceae, and Vernonia.

Palynofacies were represented predominantly by opaque, solid phytoclasts and pseudoamorphous phytoclast. It varies from $2 \%$ from palynomorph zone I to $79 \%$ from palynomorph zone IV. The probable origin of phytoclasts opaque was carbonized wood. Climate was evidently dryer and more continental.

$V$ zone, depth $30-70 \mathrm{~cm}$, peat. Algal palynomorphs decreased. Only zygospores of Spirogyra were met. Fungal palynomorphs consisted of aquatic freshwater fungi Brachysporium, and informal taxa (Dicellaeporisporites, Dicellaesporites, and Dydimoporisporonites). Other fungi were represented by Clastesporium, Neurospora, Gelasinospora, and Glomus. Algae Closterium, indicative for the environments of higher 

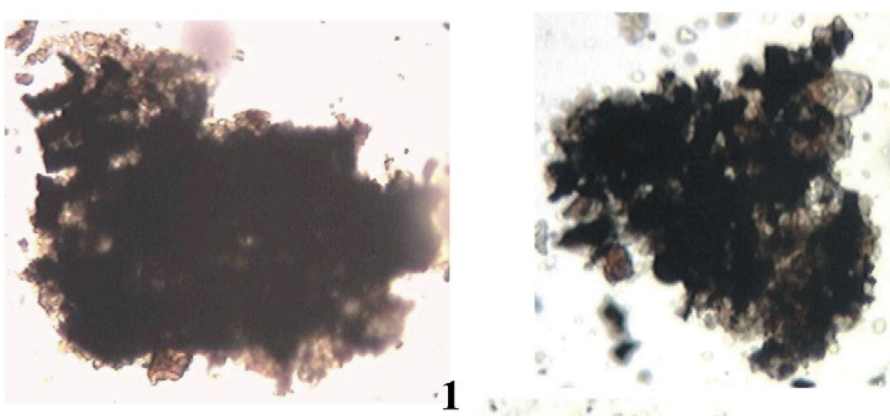

1

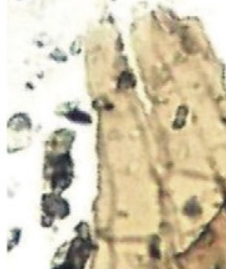

$+\infty$

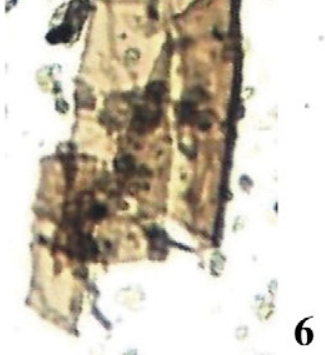

$\therefore-1=0,3+4$

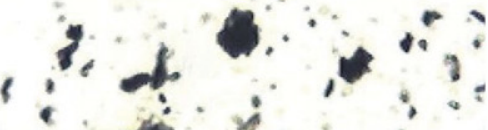

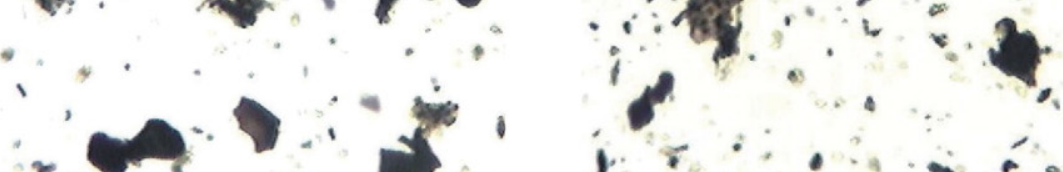

T.

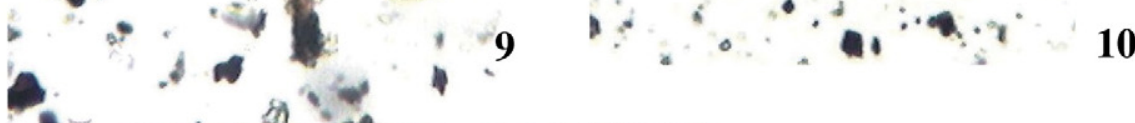

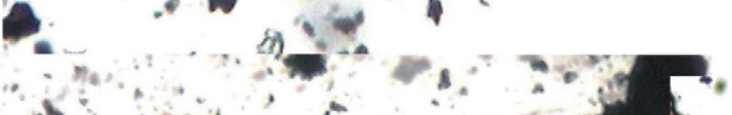

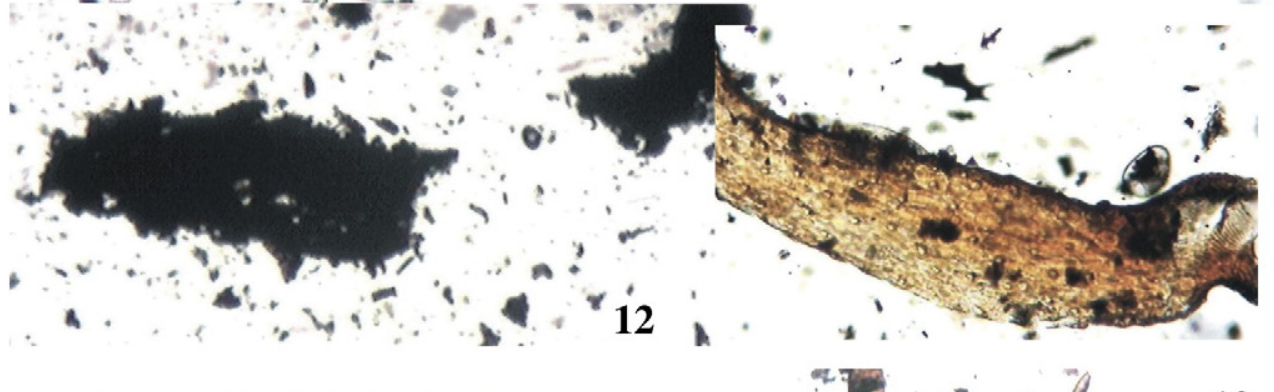

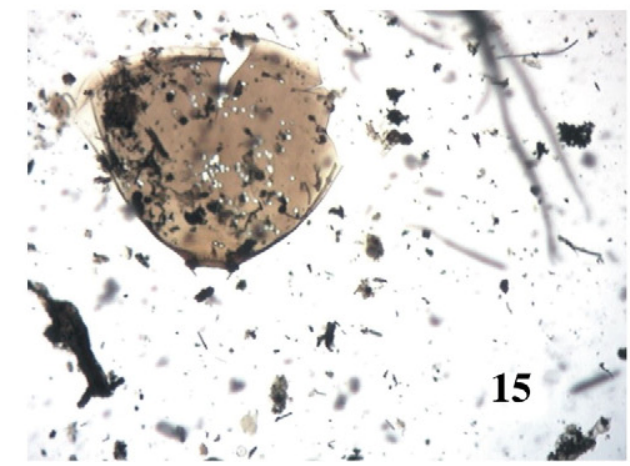

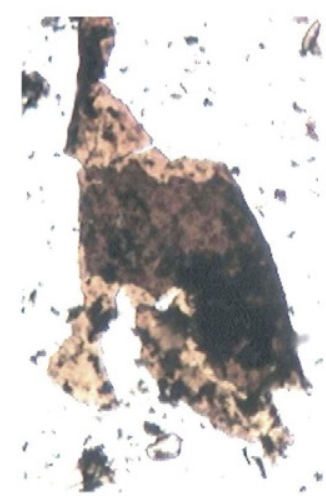
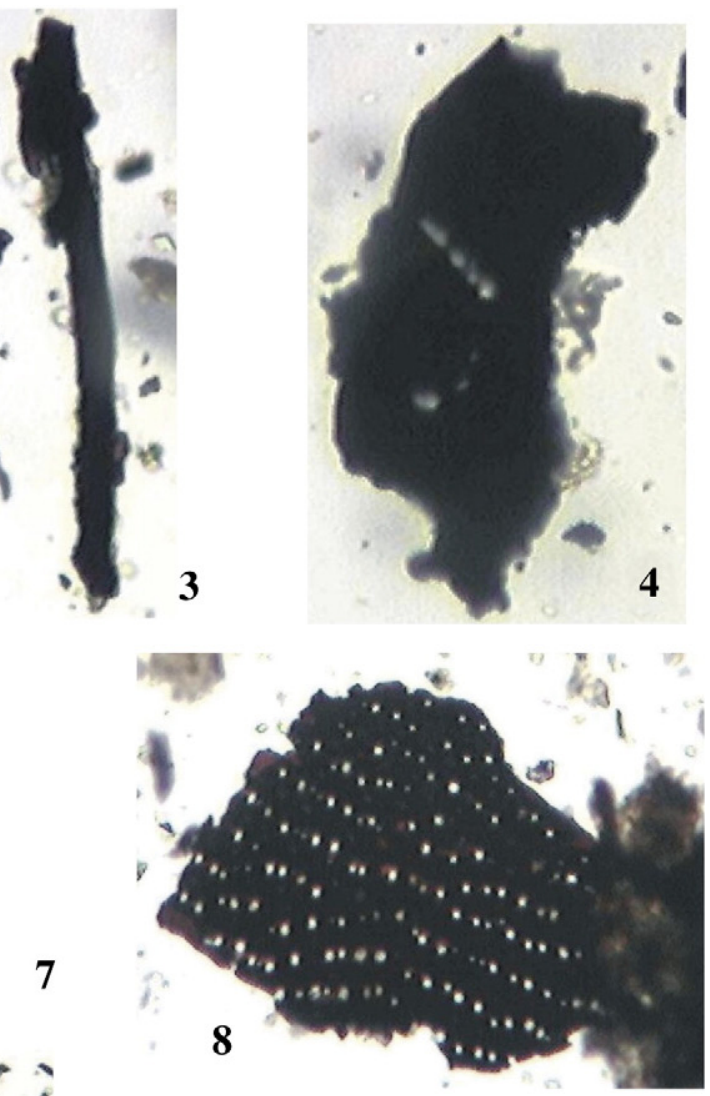

10

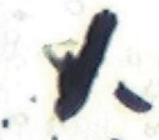

(15)

$y_{3} 3$
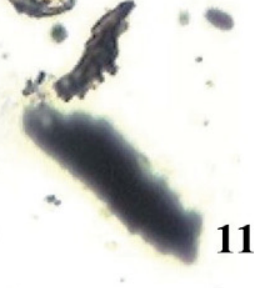

13
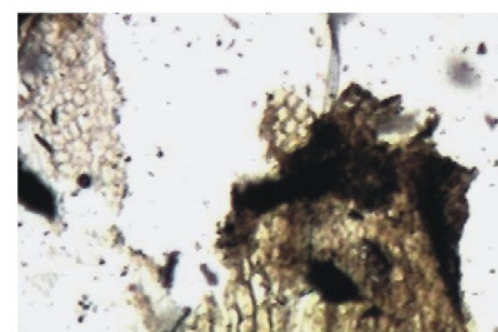

X)

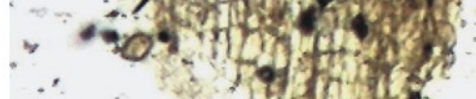

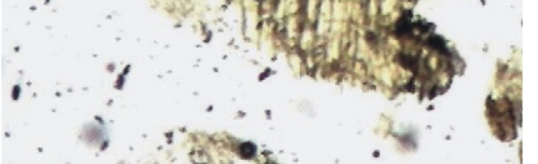

16

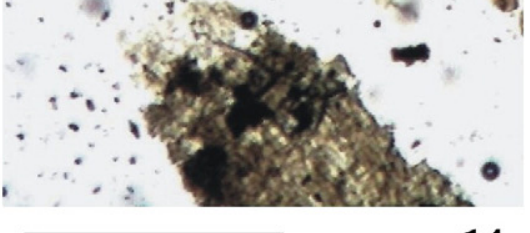


Table 2

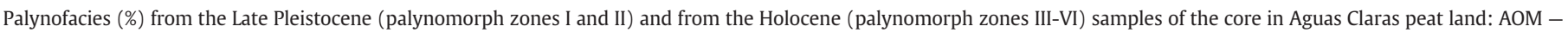
amorphous organic matter, Ps - pseudoamorphous phytoclast, Phy - phytoclast group, and Pal - palynomorph group.

\begin{tabular}{|c|c|c|c|c|c|}
\hline Depth, cm & Zone & AOM & Ps & Phy & Pal \\
\hline \multirow[t]{2}{*}{$0-30$} & VI & 68 & 20 & 9 & 3 \\
\hline & & 26 & 49 & 0 & 25 \\
\hline \multirow[t]{2}{*}{$30-70$} & V & 34 & 60 & 0 & 6 \\
\hline & & 0 & 40 & 58 & 2 \\
\hline \multirow[t]{3}{*}{$70-115$} & IV & 0 & 20 & 79 & 1 \\
\hline & & 0 & 34 & 66 & 0 \\
\hline & & 0 & 45 & 54 & 1 \\
\hline 115-135 & III & 0 & 24 & 75 & 1 \\
\hline \multirow[t]{3}{*}{$135-220$} & II & 62 & 27 & 7 & 4 \\
\hline & & 45 & 41 & 6 & 8 \\
\hline & & 57 & 24 & 16 & 3 \\
\hline \multirow[t]{2}{*}{$220-320$} & I & 35 & 43 & 7 & 15 \\
\hline & & 68 & 25 & 2 & 5 \\
\hline
\end{tabular}
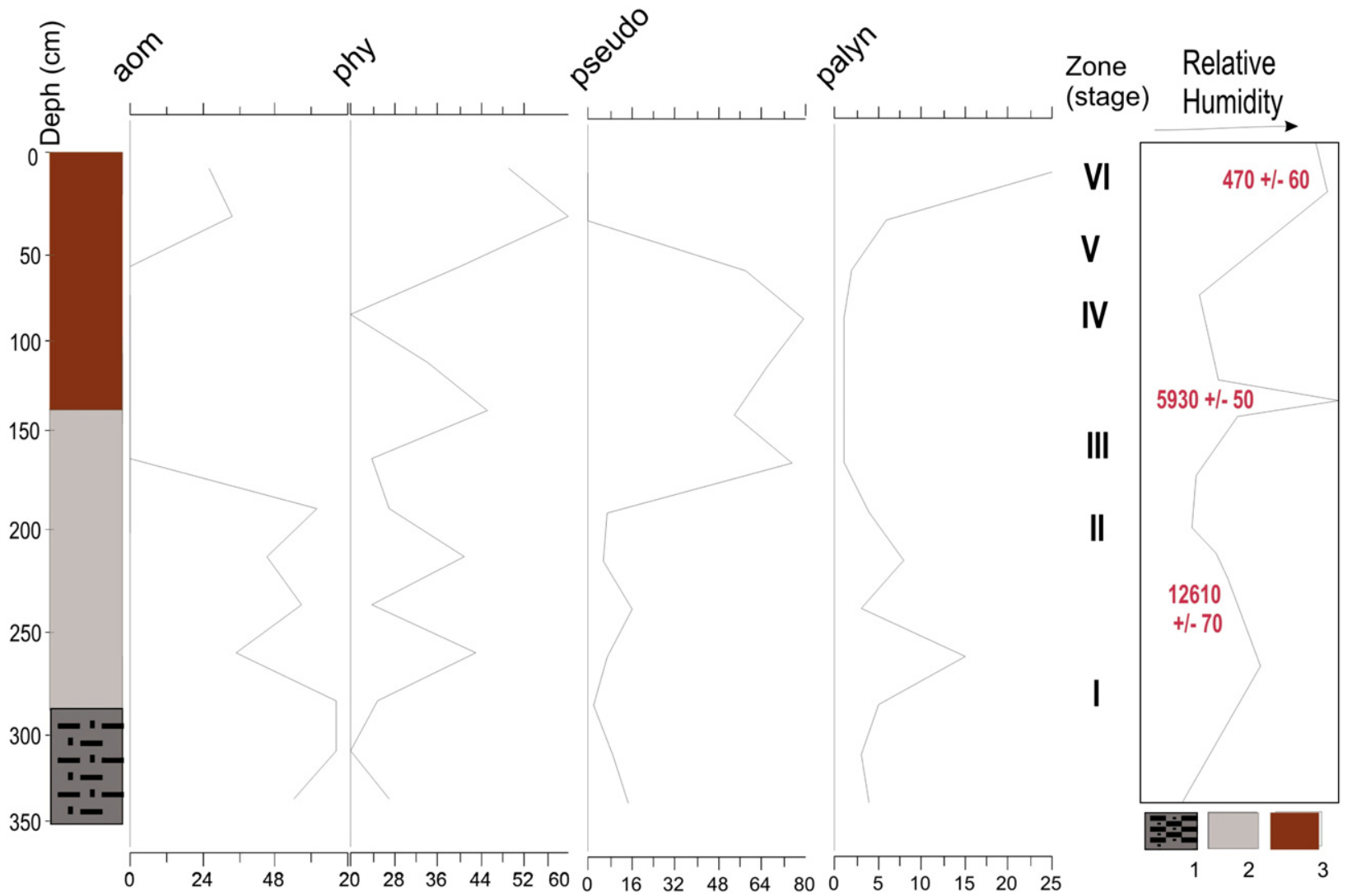

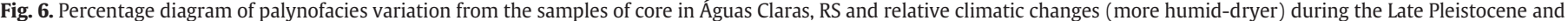

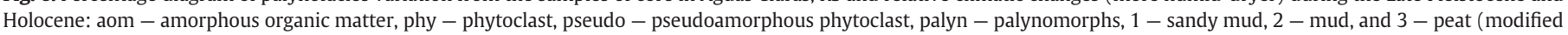
from Barbosa et al., 2003).

acidity usually associated in palynological slides with pollen of Cyperaceae and spores of Sphagnum (Medeanic, 2006), was relatively frequent.

Palynofacies showed phytoclast predominance (Table 2). Frequent phytoclasts, composed of both translucent and opaque plant particles might be associated with water table fluctuations. In comparison with previous phase, we supported that climate became more humid.

VI zone, depth 0-30 cm, peat. Algal palynomorphs were frequent, and various Spirogyra zygospores were frequent. Other freshwater algal palynomorphs were represented by Debarya, Zygnema, Closterium, Coelastrum, Pseudoschizaea, Scenedesmus, and Mougeotia. Probably, we have had records for the Little Ice Period from the sample at the depth of $15 \mathrm{~cm}$ dated by ${ }^{14} \mathrm{C}$ as $470 \pm 80$ yrs BP where algal palynomorphs Debarya were registered. This algal palynomorph may serve as indicator for the lower temperatures (van Geel and van der Hammen, 1978). Taxonomic diversity of fungal palynomorphs increased. They were represented by informal taxons (Dicellaeporisporites, Dicellaesporites, Dydimoporisporonites, Fusiformisporites, and Lacrimasporonites), freshwater aquatic (Brachysporium and Helicoon),

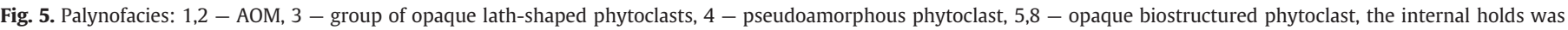

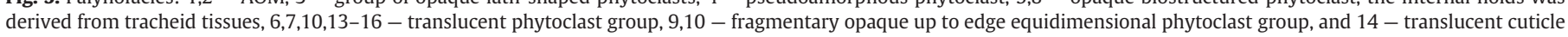
phytoclast showing regular cell outline. Scale $-30 \mu \mathrm{m}$. 
cellulose decomposed (Chaetomium), and dung-coprophilous (Podospora, Sordaria, and Sporormiella). Besides, fungi Tilletia, parasitism on seed of grasses was recorded (Tilletia online). In this zone, fungal palynomorphs of Byssothecium cf. circinans which usually grows on woody substrate were encountered. Indicative for the peat fungal palynomorph Clastesporium, commonly associated with Cyperaceae and Sphagnum, were met. Fungal palynomorphs of Valsaria, characteristic for the wet eutrophic conditions were rare. Variety of fungal palynomorphs was highest from the surface sample of the peat than from other studied samples. Palynomorphs of fungi of Coniochaeta that usually grow in the high population density regions were registered in association with parasitic and dung coprophilous fungal palynomorphs reflecting occupation of this peatland by rural population.

Palynofacies consisted mainly of pseudoamorphous phytoclast showing evidence of homogeneous oxidation. Also, non-fluorescent, rounded, diffuse AOM were met, whose probable origin was connected with degraded matter from the land. There was an increase in AOM and palynomorph contents till 25\% (Table 2). Deposition of this zone occurred under relatively humid climate subjected by dense anthropogenic impact.

According to the above results, palynofacies characterized by AOM predominance were described from palynomorph zones I and II (the Late Pleistocene) that consisted of mud (Fig. 2). They were associated with relatively frequent fungal palynomorphs of Gelasinospora and Glomus, indicative for dryer and more continental climate.

Holocene peat samples show AOM varying from $68 \%$ in zone I and decrease till nil in zones III, IV, and V. It was amorphous mass, not fluorescent and probably originated from degraded land organic matter. Phytoclast group was the most important from the samples. In general, less dark brown structure pseudoamorphous phytoclasts), translucent or opaque (charcoal) constituents and fungal debris occurred. The limit Late Pleistocene/Holocene (zone II) was signed by an increase in pseudoamorphous phytoclasts, which were also of high frequency in zones IV and V. Phytoclasts were less dark brown structure (pseudoamorphous phytoclasts) in zones III, $\mathrm{IV}$, and V. At the top of the Holocene succession (zone VI), decreasing of pseudoamorphous content to nil was notable. In this zone, phytoclast group was mainly translucent, opaque material and also fungal debris was followed by amorphous ground matter nonfluorescent from the land. Opaque phytoclasts consisted of black or almost black equidimensional structureless material. Probably, these phytoclasts originated from transported oxidized or carbonized wood.

Chemical oxidation was an important process of organic matter degradation in the palynofacies I and II (mud facies). The higher proportion of AOM, probably land origin from zones I and II, and also pseudoamorphous dominance in III, IV, and V zones compared with the phytoclast might be associated with water table fluctuations and an increase in organic matter degradation in the peat. In those zones, algal palynomorph frequencies and their variety notably increased in comparison with fungal palynomorphs. In the same way, the opaque particles include heterogeneous constituents that could have various origins, such as combustion residues (i.e. charcoal), strongly altered and oxidized phytoclasts created by repeated cycles of degradation (i.e. charcoal-like phytoclasts) (Batten, 1996; Tyson, 1995). In some samples charcoal particles were accompanied by fungal palynomorphs of Neurospora indicative for fires. Broken grain occurrences suggest some transportation during sediment deposition and formation of palynofacies. The degraded phytoclasts (some with pits) were probably associated with an intense oxidation. The higher proportion of AOM during the Late Pleistocene (zones I and II) compared with the phytoclast group from the Holocene samples (zones III-IV) suggests the dominance of decantation over traction processes with important deterioration of the organic matter. The low content of palynomorphs in almost all samples indicates a destruction of palynomorphs, probably, due to successive alteration in the water level table during deposition.

\section{Conclusions}

Study of NPPs and palynofacies from the Holocene and Late Pleistocene samples from one core in southern Brazil revealed diverse algal and fungal palynomorphs accompanied by different organic debris (AOM, phytoclasts, and charcoal particles). They were used for reconstructions of palaeoenvironments and paleoclimate oscillations that occurred during the Late Pleistocene and the Holocene.

In the Late Pleistocene, until peat deposition climate was dry and colder than actual, relatively scarce algal and fungal palynomorphs and predominance of amorphous organic matter were confirmed. Higher proportion of AOM suggests important deterioration of the organic matter.

In comparison with the Late Pleistocene underlying layer, peat was characterized by more varieties of algal and fungal palynomorphs. Deposition of the Holocene peat occurred under more humid climate and higher temperatures but climate was oscillating from time to time: dryer-more humid that was well shown by NPPs, changes in proportion algal/fungal palynomorphs and by types of organic matter.

Algal palynomorph diversity (Mougeotia, Spirogyra, Pseudoschizaea, and Scenedesmus) and increasing relative frequency were indicated on more humid conditions.

Botryococcus associated with relative frequent Glomus and sporadic Gelasinospora was registered in zones formed during dryer climate. Particles of charcoal sometimes were accompanied by Neurospora, which usually occupied carbonized rests of plants.

The superficial sample from the peat land was characterized by notable increase in fungal palynomorph diversity. Records of aquatic fungi (Brachysporium and Helicoon) may indicate both in more humidity and probably an increase in eutrophication of the land as a result of wide occupation of this peat land and development of agricultural activities. Domestic activity expansion may be a reason of frequent dung-coprophilous fungi (Podospora, Sordaria, and Sporormiella), and parasitic activity on seed of grasses of fungi Tilletia.

Combined applications of NPPs and palynofacies analyses provide a valuable method for paleoenvironmental and paleoclimatic reconstructions. The obtained data contribute for better understanding of the Holocene peat evolution in southern Brazil.

\section{Acknowledgments}

We are grateful to anonymous reviewers, Dr. Özgen Karacan and Dr. João Graciano for their useful comments, corrections and suggestions that significantly improved this manuscript.

\section{References}

Barbosa, E.G., Medeanic, S., Guerra-Sommer, M., Cazzulo-Klepzig, M., 2003. Aplicação da Palinologia como subsídio para o estudo estratigráfico da turfeira de Águas Claras. Anais, IX Congresso da Associação Brasileira de Estudos do Quaternário, Recife.

Batten, D.J., 1987. Application of palynofacies analysis to interpretation of palaeoenvironments and source potential for hydrocarbons. Actas, VII Simposio Argentino de Paleobotánica y Palinología. Buenos Aires, Argentina, pp. 7-14.

Batten, D.J., 1996. Palynofacies. In: Jansonius, J., McGregor, D.J. (Eds.), Palynology: Principles and Applications. AASP, Dallas, Texas, pp. 1011-1064.

Boulter, M.C., Riddick, A., 1986. Classification and analysis of palynodebris from the Paleocene sediments of the Florida Field. Sedimentology 33, 871-886.

Burjack, M.I., Marques-Toigo, M., 1980. Caracterização palinológica da Turfeira da região de águas Claras, Município de Viamão- RS, Brasil. Bol. Instituto de Geociencias, USP 11, 31-189.

Elsik, W.C., 1983. Microscopic fungal remains and Cenozoic palynostratigraphy. Geosci. Man XV 115-120.

Faegri, K., Iversen, J., 1975. Text-book of pollen analysis. Blackwell Scientific Publications. Amsterdam. 
Garcia, M.J., 1997. Palinologia de Turfeiras Quaternárias do Médio Vale do Rio Paraíba do Sul, estado de São Paulo, Brasil. Parte I: Fungos, Algas, Briófitas e Pteridófitas. Revista Universidade Guarulhos - Geociências II ( $\mathrm{n}^{\mathrm{o}}$ especial), 148-165.

Grimm, E.C., 1987. CONISS: a Tortran 77 Program for stratigraphically constrained cluster analysis by the method of the incremental sum of square. Pergamon J. 13, 13-35.

Guy Ohlson, D., 1992. Botryococcus as an aid in the interpretation of palaeoenvironment and depositional processes. Rev. Palaeobot. Palynol. 71, 1-15.

Hoshaw, R.W., McCourt, R.M., 1988. The Zygnemataceae (Chlorophyta) a twenty-year update of research. Phycol. 27, 511-548.

Jansonius, J., Kalgutkar, R.M., 2000. Redescription of some fossil fungal spores. Palynology 24 (1), 37-47.

Jarzen, D.M., Elsik, W.C., 1986. Fungal palynomorphs recovered from recent River deposits, Luangwa Valley, Zambia. Palynology 10, 35-60.

Komárek, J., Jankovská, V., 2001. Review of the green algal genus Pediastrum: implication for pollen-analytical research. Berlin, Stuttgart, Biblioteca Phycologica. J. Cramer, Berlin.

Limaye, R.B., Kumaran, K.P.N., Nair, K.M., Padmaiai, D., 2007. Non-pollen palynomorphs as potential palaeoenvironmental indicators in the Late Quaternary sediments of the west coast of India. Curr. Sci. 92 (10), 1370-1382.

Medeanic, S., 2006. Freshwater algal palynomorph records from Holocene deposits in the coastal plain of Rio Grande do Sul. Brazil. Rev. Palaeobot. Palynol. 141 (1-2), 83-102.

Medeanic, S., Lima, L., Caron, F., 2008. Palinomorfos de fungos em turfeiras holocênicas no extremo sul da planície costeira do Rio Grande do Sul (RS): A importância nas reconstruções paleoecológicas. Resume, I Encontro Gaucho de Micologia, Porto Alegre, Brazil, p. 80.

Pals, J.P., van Geel, B., Delfos, A., 1980. Paleoecological studies in the Klokkeweel bo near Hoog Karspel (prov. of Noord Holland). Rev. Palaeobot. Palynol. 30 $371-418$.

Parsons, M.G., Norris, G., 1999. Paleogene fungi from the Caribou Hills, Mackenzie Delta, northern Canada. Palaeontographica Abt. B 250 (4-6), 77-167.

Rull, V., López-Sáez, J., Vegas-Vilarrúba, T., 2008. Contribution of non-pollen palynomorphs to the paleolimnological study of a high altitude Andean lake (Laguna Verde Alta, Venezuela). J. Paleolimnol. 40, 399-411.
Süffert, T., 1998. Turfa de Águas Claras, Estado do Rio Grande do Sul. Porto Alegre: CPRM. Informe de Recursos Minerais. Série Oportunidades Minerais. Exame Atualizado de Projeto, $\mathrm{n}^{0} 13$

Traverse, A., 1988. Paleopalynology. Unwin Hyman, Boston.

Tyson, R., 1995. Sedimentary Organic Matter. Chapman and Hall, London.

van Bergen, P., Janssen, N., Alferink, J., Kerp, J., 1990. Recognition of organic matter types in standard palynological slides. In: Permont, W.J.J., Weegink, J.W. (Eds.), Proceedings of the International Symposium on Organic Petrology. Mededelingen Rijks Geologische Dienst, pp. 9-21.

van Dam, H., Mertens, A., Sinkeldam, J., 1988. A coded checklist and ecological indicator values of freshwater diatoms from the Netherlands. Neth. J. Aquat. Ecol. 28, 117-133.

van Geel, B., 1976. Fossil spores of Zygnemataceae in ditches of a prehistoric settlement in Hoogkarspel (The Netherlands). Rev. Palaeobot. Palynol. 22 (4), 337-344.

van Geel, B., 2006. "Quaternary non-pollen palynomorphs" deserve our attention! Rev. Palaeobot. Palynol. 141, 1-2 vii-viii.

van Geel, B., Andersen, S.T., 1988. Fossil ascospores of the parasitic fungus Ustulina deusta in Eemian deposits in Denmark. Rev. Palaeobot. Palynol. 56, 89-93.

van Geel, B., Aptroot, A., 2006. Fossil ascomycetes in Quaternary deposits. Nova Hedwig. $82(3,4), 313-329$

van Geel, B., van der Hammen, T., 1978. Zygnemataceae in Quaternary Colombian sediments. Rev. Palaeobot. Palynol. 25 (5), 377-392.

van Geel, B., Boncke, S.J.P., Dee, H., 1980. A palaeoecological study of the Upper Late Glacial and Holocene sequence from "de Borchert" the Netherlands. Rev. Palaeobot. Palynol. 31 (3, 4), 367-448.

van Geel, B., Bos, J.M., Pals, J.P., 1986. Archaeological and palaeoecological aspects of a medieval house terp in a reclaimed raiseg bog area in North Holland. Ber. Rijksd. Oudheidkd Bodemonderz 33, 419-444.

van Geel, B. Buurman, J. Brinkkemper, O Schelvis, J., Aptroot, A, van Reenen, G. Hakbijl, T., 2003. Environmental reconstruction of a Roman Period settlement site in Uitgeest (The Netherlands) with special reference to coprophilous fungi. J. Archaeol. Sci. 30, 873-883.

Villwock, J.A., Dehnhardt, E.A., Loss, E.L., Hofmeister, T., 1980. Turfas da Província Costeira do Rio Grande do Sul - Geologia do Depósito de Águas Claras. Anais, $31^{\circ}$ Congresso Brasileiro de Geologia, Balneário de Camboriú, Brasil, p. 514. 